\title{
A Measurement of Construct Validity and Reliability of Servant Leadership
}

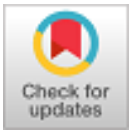

\author{
Arifah, Fatwa Tentama, Pipih Muhopilah
}

\begin{abstract}
The purpose of this study is to test the construct validity and reliability on the scale of servant leadership and aspects and indicators that can form this variable. Servant leadership is measured by five aspects, namely humility, love, vision, empowerment and trust. The population in this study are all Early Childhood Education teachers in Jetis District, Bantul Regency, with a sample of 60 people. The sampling technique used in this study is cluster random sampling. The data collection method is servant leadership scale. Research data are analyzed using Structural Equation Modeling (SEM) through the SmartPLS 3.2.8 program. Based on the results of data analysis, the aspects and indicators that made up the servant leadership variable were declared valid and reliable. The most dominant aspect that reflects servant leadership was trust with a loading factor value of 0.779 and the weakest aspect that reflects this variable was humility with a loading factor value of 0.568 . It shows that all aspects and indicators are able to reflect and shape servant leadership variable. Thus, the measurement model can be accepted because the theory presented by the servant leadership variable is in accordance with the empirical data obtained from the subject.

Keywords: Servant Leadership, Humility, Love, Vision, Empowerment
\end{abstract}

\section{INTRODUCTION}

Leadership is one of the most important things for an organization's success. The leader has the role to make decisions that are important to the organization, determine the goals and programs of the organization, to socialize organizational goals to employees, and to manage human resources so that all employees can work well. On the other hand, the changes that often occur both within the organization and outside the organization also require leaders to be able to overcome the various challenges that arise. Given the important role of a leader, the leadership style of a leader is important to note. One important leadership style to be applied at this time is servant leadership [1].Servant leadership is a leadership style that is more focused on serving others [2]. The main purpose of servant leadership is to serve and meet the needs of employees [3]. Leaders with this leadership style strive to make employees wanting to try and develop [4].

Revised Manuscript Received on February 05, 2020.

* Correspondence Author

Arifah, Master of Psychology*, Ahmad Dahlan University, Yogyakarta, Indonesia. Email: arifah240476@gmail.com

Fatwa Tentama*, Master of Psychology, Ahmad Dahlan University, Yogyakarta, Indonesia. Email: fatwa.tentama@psy.uad.ac.id

Pipih Muhopilah, Master of Psychology, Ahmad Dahlan University, Yogyakarta, Indonesia. Email: pipihmuhopilah7@gmail.com

(c) The Authors. Published by Blue Eyes Intelligence Engineering and Sciences Publication (BEIESP). This is an open access article under the CC BY-NC-ND license (http://creativecommons.org/licenses/by-nc-nd/4.0/)
Servant leadership has various positive impacts such as increasing customer value co-creation (CVC) [5], increasing service-orientated behavior and service quality on employees [6], increasing employee trust in leaders [7], predicting commitment, satisfaction and intentions to stay on employees [8], increasing work engagement [9] and increasing employee commitment [10].

Other results show that servant leadership is related to employee behavior and organizational citizenship behavior [11], and positively correlated with company and employee performance and employee creativity [12]. In contrast, servant leadership is negatively correlated with narcissistic behavior in leaders [13] and employee turnover [12]. Servant leadership is motivated by various factors, including the existence of trust and commitment to the organization [14], the status of the leader as the founder [13], as well as personality and motivation [15].

Servant leadership was initially popularized by Robert Greenleaf [16] in his essay which suggested the importance of leaders to develop the potential of their subordinates and set a good example for them. However, even though this initial concept of leadership already exists, the development of research on servant leadership has only begun to develop since the research of Ehrhart [17]. The development of research on servant leadership then progressed; his research not only focuses in the scope of individuals but also in organization [18].

The development of research on servant leadership can be categorized into three phases. The first phase is the development phase of the concept of servant leadership. This phase focuses on the writings and research results of Greenleaf [16] and Spears [19]. The second phase is the development phase of servant leadership measurement. This phase is marked by the development of servant leadership measurement tools and test to reveal the relationship between servant leadership with various other variables. The third phase is the servant leadership research phase. This phase is marked by the development of more sophisticated research designs, in this phase research is conducted to understand the causes, mediators and structural models of servant leadership [20].

Servant leadership is a style of leadership that makes service a primary goal. Leaders strive to develop the resources of their subordinates [16]. Then Ehrhart [17] defines servant leadership as leadership that aims to achieve organizational goals and develop subordinates, 
consumers and all stakeholders of the organization. Servant leadership is a holistic leadership approach that involves the relational, rational, ethical, emotional and spiritual aspects of the leader and its members, so that they are jointly transformed to develop and achieve goals [21].

Research on servant leadership continues to develop, in the third phase of the development, this variable leads to its relationship with other variables [20]. Recent studies have suggested that servant leadership is positively correlated with performance and proactive attitudes towards employees [22], cross-cultural studies show that the positive effect of servant leadership on this performance occurs significantly in the Asian region [23]. Other recent research results also show that servant leadership increases knowledge sharing behavior among employees [24], increases job satisfaction and life satisfaction [25]-[26], and increases teamwork effectiveness [27]. It can directly increase employee confidence and creativity and reduce the intention to be late at work [28]. In a company led by women, servant leadership also has a positive influence on organizational commitment and organizational behavior of employees [29]. In addition to organizational settings, servant leadership has also begun to be developed in early childhood [30], and school counselors [31].

According to Irving [32] there are five aspects of servant leadership. The first aspect is love. Love in servant leadership refers to the moral love that motivates individuals to do the right thing at the right time and for the right reasons. Love for servant leadership is manifested by sincere concern for employees, interest in the lives of employees and respect in which leader feel employee's presence as meaningful. The second aspect is empowerment and this aspect emphasizes the importance of teamwork. Empowerment is demonstrated by the belief in giving tasks to others, the willingness to listen to the opinions of employees, emphasizing the importance of teamwork and the role of each individual, as well as placing all members equally and appreciating them.

The third aspect of servant leadership is vision. The leader has a clear vision, openness about the goals of the organization and is able to organize strategies to achieve that vision so that the team can work effectively. The fourth aspect is humility. Leaders show modesty by showing respect for employees and acknowledging their contribution to the team. The fifth aspect is trust. Trust in servant leadership is demonstrated by the belief in its employees, so that the team can work openly and effectively.

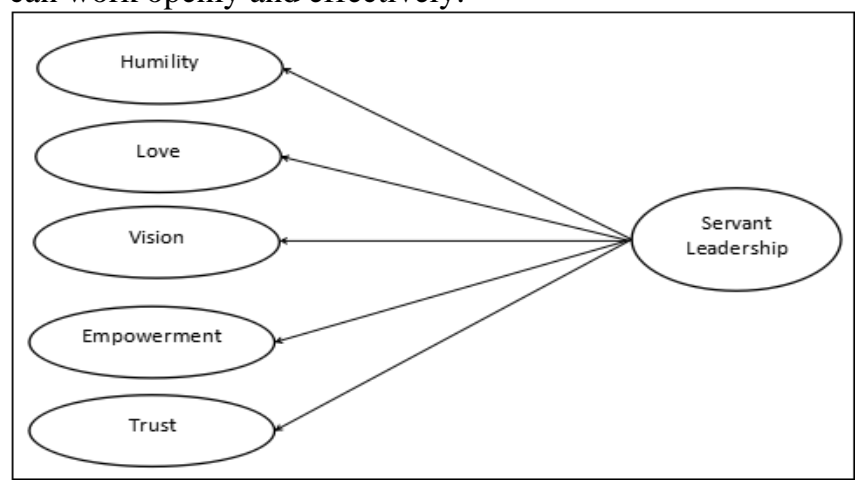

Fig. 1. Conceptual model of servant leadership

Based on Figure 1 above, the hypotheses in this study are: 1) A servant leadership scale measurement model is compatible with empirical data. 2) The servant leadership aspects such as humility, love, vision, empowerment and trust are able to form servant leadership variables.

One approach that can be used in testing the construction of a measuring instrument is Confirmatory Factor Analysis (CFA). Confirmatory Factor Analysis (CFA) is one of the main approaches in factor analysis. It can be used to test aspects of a construct. This test is used to measure the model (model measurement) so that it can describe aspects and indicators of behavior in reflecting latent variables (servant leadership) by looking at the loading factor of each aspect that forms the construct. Confirmatory Factor Analysis (CFA) is also used to test the construct validity and construct reliability of the indicators (items) forming latent constructs [33]. Confirmatory Factor Analysis (CFA) used in this study is the second order Confirmatory Factor Analysis ( $\left(2^{\text {nd }}\right.$ Order CFA), a measurement model that consists of two levels. The first level of analysis is carried out from aspects to its indicators and the second analysis is carried out from latent variables to its aspects [34].

Based on the description above, the problem formulations in this study are: 1) Is the scale of servant leadership valid and reliable? 2) Are the aspects of humility, love, vision, empowerment and trust able to form servant leadership variables? The purpose of this study is to: 1) Test the validity and reliability of the servant leadership scale and 2) examine the aspects and indicators that can form the servant leadership variables.

\section{RESEARCH METHOD}

\section{A. Population, Sample and Sampling Technique}

The population in this study were all Early Childhood Education teachers in Jetis District, Bantul Regency. The sample in this study consists of 60 Early Childhood Education teachers. The sampling technique used in this study is cluster random sampling technique.

\section{B. Data Collection Method}

Servant leadership is measured using a scale composed based on a Likert scaling model. The scale in this study was compiled by researchers with reference to aspects of servant leadership according to Irving [32], namely humility, love, vision, empowerment and trust. Example of items on the aspect of humility is "Principal appreciates the work of teachers" and example of items in the aspect of love is "The principal asks the employee's family conditions". Example of items in the vision aspect is "Principal explain the long-term goals of the organization". Example of items on the aspect of empowerment is "Principal is willing to listen to the opinions of teachers", and examples of items from aspect of trust is "Principal delegates tasks to teachers". Blueprints that are used as a reference in the preparation of servant leadership scale can be seen in table 1 .

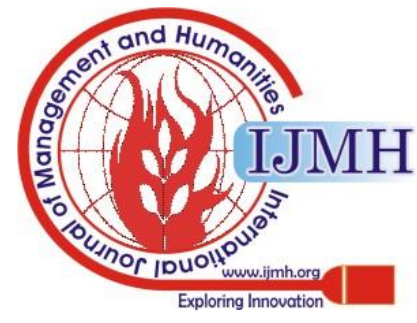


Table 1. Blueprint of servant leadership scale

\begin{tabular}{|c|c|c|c|c|}
\hline \multirow{2}{*}{ Aspect } & \multirow{2}{*}{ Indicator } & \multicolumn{2}{|c|}{ Item Number } & \multirow{2}{*}{$\Sigma$} \\
\hline & & Favorable & Unfavorable & \\
\hline Love & $\begin{array}{l}\text { 1. Care for employees } \\
\text { 2. Care for employees`s } \\
\text { life } \\
\text { 3. Make employees feel } \\
\text { meaningful }\end{array}$ & $\begin{array}{c}7,17,20 \\
29\end{array}$ & $\begin{array}{c}12,22,39 \\
40\end{array}$ & 8 \\
\hline $\begin{array}{l}\text { Empow } \\
\text { erment }\end{array}$ & $\begin{array}{l}\text { 1. Entrust duties to others } \\
\text { 2. Want to listen to the } \\
\text { opinions of employees } \\
\text { 3. Concerned about } \\
\text { teamwork and the role of } \\
\text { each individual } \\
\text { 4. Respect all members and } \\
\text { place them equally }\end{array}$ & $\begin{array}{c}2,6,13 \\
36\end{array}$ & $8,15,25,27$ & 8 \\
\hline Vision & $\begin{array}{l}\text { 1. The leader has a clear } \\
\text { vision } \\
\text { 2. Openness regarding } \\
\text { organizational goals } \\
\text { 3. Able to develop } \\
\text { strategies to achieve the } \\
\text { organization's vision }\end{array}$ & $\begin{array}{c}5,21,24 \\
30\end{array}$ & $9,23,31,11$ & 8 \\
\hline $\begin{array}{l}\text { Humilit } \\
\mathrm{y}\end{array}$ & $\begin{array}{l}\text { 1. Respect employees } \\
\text { 2. Recognize employee } \\
\text { contributions }\end{array}$ & $\begin{array}{c}\text { 32, } 33,35 \\
38\end{array}$ & $4,28,34,37$ & 8 \\
\hline Trust & $\begin{array}{l}\text { 1. Show confidence in } \\
\text { employees } \\
\text { 2. Working openly }\end{array}$ & $\begin{array}{l}1,10 \\
16,18\end{array}$ & $3,14,19,26$ & 8 \\
\hline & Total & 20 & 20 & 40 \\
\hline
\end{tabular}

\section{Construct Validity}

To test the construct validity and construct reliability, this study uses the outer model testing through the smartPLS 3.2.8 program. The construct validity test was conducted to show the ability of each item or indicator (observed variable) to reflect each aspect and to reflect the variable (laten variable).

The construct validity test consists of convergent and discriminant validity tests. The convergence validity can be seen from the loading factor and the Average Variance Extracted (AVE) value of $>0.5$ [35]. According to Hair, Hult, Ringle, and Sartedt [36] the higher the loading factor score, the more important the role of loading will be in interpreting the factor matrix. Loading factor and AVE value of $>0.5$ are considered significant [34]. While discriminant validity can be seen from comparing the roots of the Average Variance Extracted (AVE) between aspects in which it must be higher than the correlation with other aspects [34].

\section{Construct Reliability}

The construct reliability test was conducted to show the internal consistency of the measuring instrument by looking at the value of composite reliability and Cronbach alpha with a higher value. It would show the consistency value of each item in measuring latent variables. According to Hair, Hult, Ringle, and Sartedt [36] the expected composite reliability and Cronbach alpha values are $>0.7$ although 0.6 values are still acceptable [34].

\section{E. Data Analysis}

The data in this study were analyzed using the outer model with the CFA $2^{\text {nd }}$ Order approach through the SmartPLS 3.2.8 program. According to Abdillah and Hartono [36] Partial Least Square (PLS) is a variant-based Structural Equation Model (SEM) that can simultaneously test measurement models to test validity and reliability.

\section{RESULT}

The test results of the servant leadership scale outer model using the SmartPLS 3.2.8 program can be seen in Figure 2 below.

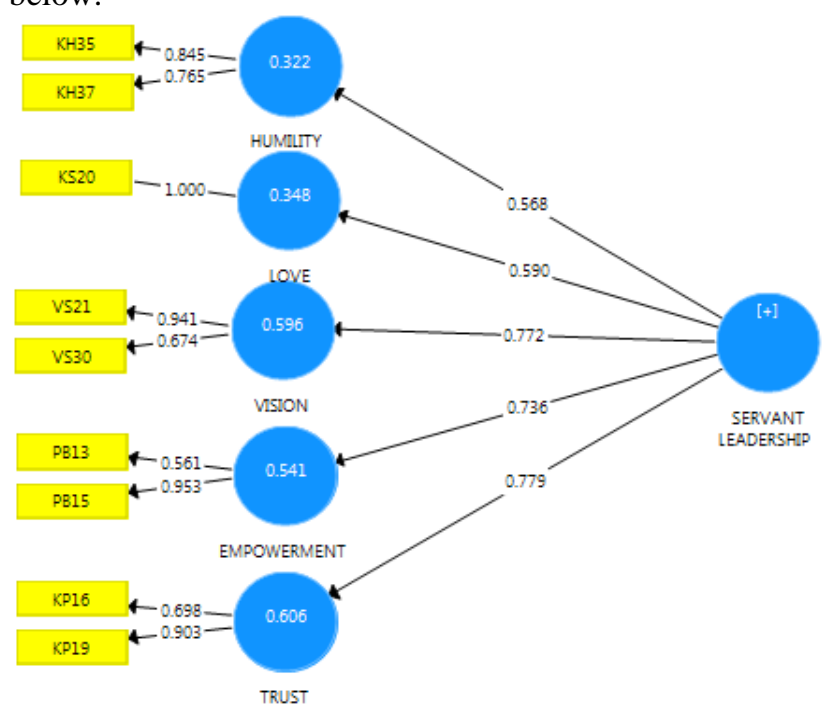

Fig. 1. Output outer model of servant leadership scale

\section{A. Construct Validity Test Result}

\section{Convergent Validity}

Convergent validity test results are performed by testing the outer model seen from the loading factor value and Average Variance Extracted (AVE). This test is done by looking at the loading factor and AVE value of $>0.5$. Based on the data analysis, it was found that the value of loading factors from variables to aspects and from aspects to indicators are $>0.5$. Loading factor values of above 0.5 or more are considered strong enough to explain and validate latent constructs [35]. The results of convergent validity testing can be seen in table 2 and table 3 .

Table 2. Loading factor value (variable-aspect)

\begin{tabular}{|l|c|c|}
\hline \multicolumn{1}{|c|}{ Aspect } & Loading Factor & Explanation \\
\hline Humility & 0.568 & Valid \\
\hline Love & 0.590 & Valid \\
\hline Vision & 0.772 & Valid \\
\hline Empowerment & 0.736 & Valid \\
\hline Trust & 0.779 & Valid \\
\hline
\end{tabular}

Table 3. Loading factor value (aspect-item)

\begin{tabular}{|l|c|c|}
\hline \multicolumn{1}{|c|}{ Item } & Loading Factor & Explanation \\
\hline KH35 & 0.845 & Valid \\
\hline KH37 & 0.765 & Valid \\
\hline KS20 & 1.000 & Valid \\
\hline VS21 & 0.941 & Valid \\
\hline VS30 & 0.674 & Valid \\
\hline PB13 & 0.561 & Valid \\
\hline PB15 & 0.953 & Valid \\
\hline KP16 & 0.698 & Valid \\
\hline KP19 & 0.903 & Valid \\
\hline
\end{tabular}

Convergent validity test results show that the value of Average Variance Extracted (AVE) is $>0.5$. The Average Variance Extracted (AVE) value of the servant leadership variable is 0.530 and the Average Variance Extracted (AVE) value of each aspect can be seen in table 4 .

Published By:

Blue Eyes Intelligence Engineering

\& Sciences Publication

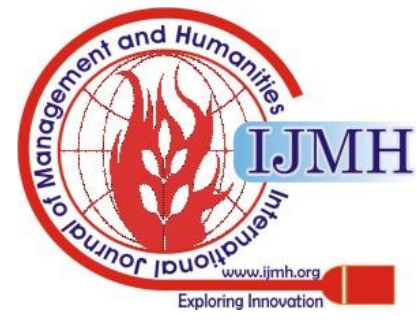


Table 4. Average variance extracted (AVE) value

\begin{tabular}{|l|c|c|}
\hline \multicolumn{1}{|c|}{ Aspect } & AVE & Explanation \\
\hline Humility & 0.650 & Valid \\
\hline Love & 1.000 & Valid \\
\hline Vision & 0.670 & Valid \\
\hline Empowerment & 0.611 & Valid \\
\hline Trust & 0.651 & Valid \\
\hline
\end{tabular}

2. Discriminant Validity

The results of discriminant validity test shows that the root value of the Average Variance Extracted (AVE) in each aspect is higher than AVE value in other aspects, so the discriminant validity criteria are met. The AVE root value of servant leadership variable can be seen in table 5 .

Table 5. AVE root value of servant leadership

\begin{tabular}{|l|c|c|c|c|c|}
\hline \multicolumn{1}{|c|}{ Aspect } & Humility & Love & Vision & Empowerment & Trust \\
\hline Humility & 0.806 & 0.291 & 0.592 & 0.535 & 0.385 \\
\hline Love & 0.291 & 1.000 & 0.319 & 0.263 & 0.357 \\
\hline Vision & 0.592 & 0.391 & 0.819 & 0.488 & 0.478 \\
\hline Empowerment & 0.535 & 0.263 & 0.488 & 0.782 & 0.496 \\
\hline Trust & 0.385 & 0.357 & 0.478 & 0.496 & 0.807 \\
\hline
\end{tabular}

\section{B. Construct Reliability Test Result}

Construct reliability testing is done by testing the outer model which is seen from the value of composite reliability and Cronbach alpha. This test is done by looking at the value of composite reliability and Cronbach alpha $>0.7$ which means that the scale in this study is reliable. The composite reliability and Cronbach alpha values can be seen in table 6 .

Table 6. Composite reliability and Cronbach alpha value of servant leadership variable

\begin{tabular}{|c|c|c|c|}
\hline Variable & $\begin{array}{c}\text { Composite } \\
\text { Reliability }\end{array}$ & Cronbach Alpha & Explanation \\
\hline $\begin{array}{c}\text { Servant } \\
\text { Leadership }\end{array}$ & 0.713 & 0.700 & Reliable \\
\hline
\end{tabular}

The results of construct reliability testing in table 6 shows that the scale of servant leadership has good reliability and means that the aspects that measure servant leadership variables meet unidimensional criteria [37]. This is indicated by the composite reliability value of 0.713 and Cronbach alpha of 0.700 . Based on the analysis of research data using the outer model testing shows that the measurement model can be accepted, because all aspects are able to reflect the variables formed.

\section{DISCUSSION}

Based on the results of the analysis of construct validity and construct reliability, the aspects and indicators that make up the scale of servant leadership are declared valid and reliable. This shows that all aspects and indicators are able to reflect and shape servant leadership variables. The most dominant aspect that is able to reflect servant leadership is trust with a loading factor of 0.779 . Trust is shown by the trust of the leader in his employees and openness to work. However, valid and reliable indicators show that leaders still carry out tasks that should be done by their employees and only trust a few people to be given certain tasks. According to Atkinson and Butchers [38] trust makes leaders showing possitive expectation that employees are competent people. The results of this study are relevant to previous studies which also found that trust reflects servant leadership [39]-[40].

Furthermore, the weakest aspect of reflecting servant leadership is humility, with a loading factor of 0.568 . Humility is illustrated by the modesty of the leader, and the leader respects and recognizes the contribution of each team member. Valid and reliable indicators show that leaders are willing to listen to the opinions of their employees, leaders do not despise their employees and always respect their employees. The low role of humility for servant leadership can be caused by several factors, including the low hierarchical position of leaders and the difference in beliefs between leaders and employees [41] - [42].

revious studies regarding the servant leadership variables that are relevant to this study and also explain the validity and reliability include the Rasheed, Lodhi and Habiba [43] studies that show that the servant leadership scale meets the reliability requirements with a Cronbach alpha value of 0.643. Then in the research of Al Amiri, Daradkeh, and Al Kaabi [44] servant leadership fulfills the reliability requirements with Cronbach alpha 0.674 . The results of this study when compared with the results of this study indicate that the scale of servant leadership from the results of this study is also feasible to be used as an instrument to reveal servant leadership, because the analysis results show that the scale of servant leadership in this study has better validity and reliability and reliable with composite reliability of 0.713 and Cronbach alpha of 0.700 .

The results of this study are expected to provide an overview of the validity and reliability of the servant leadership scale, especially in revealing servant leadership in the teacher context, so that it can be used in research data collection and become a reference in subsequent research related to servant leadership.

\section{CONCLUSION}

Based on the results of the analysis and discussion it can be concluded that: 1) The scale of servant leadership meets the validity and reliability. The validity of servant leadership scale reflected from the value of loading factor, average variance extracted (AVE) and the AVE root value from the aspects, whereupon the reliability of servant leadership scale reflected from the value of composite reliability and Cronbach alpha. 2) All aspects and indicators can form servant leadership variables, namely humility, love, vision, empowerment and trust. It reflecterd from the loading factor value of every aspects. The aspect that has the most dominant influence on servant leadership is trust and the weakest aspect that reflects servant leadership is humility. In this study a servant leadership scale measurement model was formed which is in accordance with empirical data obtained from the subject.

\section{ACKNOWLEDGMENT}

The author would like to thank Ahmad Dahlan University and the Master of Psychology Programme University of Ahmad Dahlan for supporting the implementation of this research.

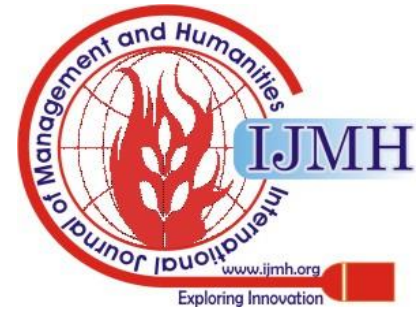




\section{REFERENCES}

1. C. Hsiao, Y.H. Lee, and W.J. Chen. (2015). The effect of servant leadership on customer value co-creation: A cross-level analysis of key mediating roles. Tourism Management, Vol. 49, pp. 45-57. https://www.sciencedirect.com/science/article/pii/S0261517715000564

2. A.G. Stone, R.F. Russell, and K. Patterson. (2004). Transformational versus servant leadership: A difference in leader focus. Leadership \& Organization

Developmen Journal.https://www.emerald.com/insight/content/doi/10.1108/0143773 0410538671/full/html?journalCode $=$ lodj

3. R.F. Russell, and A.G. Stone. (2002). A review of servant leadership attributes: developing a practical model. The Leadership \& Organization Development Journal, Vol. 23 No. 3, pp. 145-57. https://www.emerald.com/insight/content/doi/10.1108/0143773021042 4/full/html

4. T.F. McMinn. (2001). The conceptualization and perception of biblical servant leadership in the southern Baptist convention. Digital Dissertations. https://elibrary.ru/item.asp?id=5345977

5. C. Hsiao, Y.H. Lee, and W.J. Chen. (2015). The effect of servant leadership on customer value co-creation: A cross-level analysis of key mediating roles. Tourism Management, Vol. 49, pp. 45-57. https://www.sciencedirect.com/science/article/pii/S0261517715000564

6. Q. Ling, M. Lin, and X. Wu. (2016). The trickle-down effect of servan leadership on frontline employee service behaviors and performance: A multilevel study of Chinese hotels. Tourism Management, Vol. 52, pp. 341-368.

https://www.sciencedirect.com/science/article/pii/S0261517715001612

7. S. Sendjaya, and A. Pekerti. (2010). Servant leadership as antecedent of trust in organizations. Leadership \& Organization Development Journal, Vol. 31, No. 7, pp. 643-663. https://www.emerald.com/insight/content/doi/10.1108/0143773101107 9673/full/html

8. S.K. Schneider, and W.M. George. (2011). Servant leadership versus transformational leadership in voluntary service organizations. Leadership \& Organization Development Journal, Vol. 32, No. 1, pp. 60-77.

https://www.emerald.com/insight/content/doi/10.1108/0143773111109 9283/full/htm

9. D. De Clercq, D. Bouckenooghe, U. Raja, and G. Matsyborska. (2014) Servant leadership and work engagement: The contingency effects of leader-follower social capital. Human Resource Development Quarterly, Vol. 25, No. 2, pp. 183-212. https://onlinelibrary.wiley.com/doi/abs/10.1002/hrdq.21185

10. Y. Cerit. (2010). The effects of servant leadership on teachers' organizational commitment in primary schools in Turkey. International Journal of Leadership in Education, Vol. 13, No. 3, pp. 301-317. https://www.tandfonline.com/doi/abs/10.1080/13603124.2010.496933

11. F.O. Walumbwa, C.A. Hartnell, and A. Oke. (2010). Servant leadership, procedural justice climate, service climate, employee attitudes, and organizational citizenship behavior: A cross-level investigation. Journal of applied psychology, Vol. 95, No. 3, pp. 517. https://psycnet.apa.org/record/2010-09357-007

12. R.C. Liden, S.J. Wayne, C. Liao, and J.D. Meuser. (2014). Servant leadership and serving culture: Influence on individual and unit performance. Academy of Management Journal, Vol. 57, No. 5, pp. 1434-1452. https://journals.aom.org/doi/abs/10.5465/amj.2013.0034

13. S.J. Peterson, B.M. Galvin, and D. Lange. (2012). CEO servant leadership: Exploring executive characteristics and firm performance. Personnel Psychology, Vol. 65, No. 3, pp. 565-596. https://onlinelibrary.wiley.com/doi/abs/10.1111/j.1744-6570.2012.0125 3.X

14. A.J. Bambale. (2014). Relationship between Servant Leadership and Organizational Citizenship Behaviors: Review of Literature and Future Research Directions. Journal of Marketing \& Management, Vol. 5, No. 1.http://search.ebscohost.com/login.aspx?direct=true\&profile=ehost\&s 9RbRUHzaZU7sfxMydwTQkE4tkakISIlS14cT1Rj1Qp5T7Y0IT\%2FO qTcOCAHvs5Pp7BPjM5kCTWrS5zNpNxw\%3D\%3D\&crl=c

15. C.D. Beck. (2014). Antecedents of servant leadership: A mixed methods study. Journal of Leadership \& Organizational Studies, Vol. 21, No. 3 pp.

299-314 https://journals.sagepub.com/doi/abs/10.1177/1548051814529993

16. R. Greenleaf, Servant leadership. New York, NY: Paulist Press, 1997.

17. M.G. Ehrhart, (2004). Leadership and procedural justice climate as Psychology, Vol. 57, No. 1, pp. 61-94. https://onlinelibrary.wiley.com/doi/abs/10.1111/j.1744-6570.2004.tb02 484.x cope $=$ site \&authtype $=$ crawler\&jrnl $=21539715 \& A N=94196127 \& \mathrm{~h}=\mathrm{j} 3 \mathrm{vf}$ antecedents of unit-level organizational citizenship behavior. Personne

18. R.C. Liden, S.J. Wayne, J.D. Meuser, J. Hu, J. Wu, and C. Liao. (2015) Servant leadership: Validation of a short form of the SL-28. The Leadership Quarterly, Vol. 26, No. 2, pp. 254-269.

19. L. Spears. (1996). Reflections on Robert K. Greenleaf and servant-leadership. Leadership and Organization Development Journal, Vol. 17, pp. 33-35. https://www.emerald.com/insight/content/doi/10.1108/0143773961014 8367/full/html

20. N. Eva, M. Robin, S. Sendjaya, D. van Dierendonck, and R.C. Liden. (2018). Servant Leadership: A systematic review and call for future research. The Leadership Quarterly. https://www.sciencedirect.com/science/article/pii/S1048984317307774

21. S. Sendjaya., Personal and organizational excellence through servant leadership: Learning to serve, serving to lead, leading to transform. Cham: Springer, 2015

22. J.A. Varela, B. Bande, M. Del Rio, and F. Jaramillo. (2019). Servant leadership, proactive work behavior, and performance overall rating: testing a multilevel model of moderated mediation. Journal of Business-to-Business Marketing, pp. 1-19. https://www.tandfonline.com/doi/abs/10.1080/1051712X.2019.160341

23. K.K.S. Chon, and J. Zoltan. (2019). Role of servant leadership in contemporary hospitality. International Journal of Contemporary Hospitality Management. https:/www.emerald.com/insight/content/doi/10.1108/IJCHM-11-2018 $-0935 /$ full/html

24. H. Amin, F. Ahmed, and R.H. Soomro. (2019). Servant leadership improves the knowledge sharing behavior of employees in organization: A case of higher education sector in Pakistan. Etikonomi, Vol. 18, No. 1 , pp. $83-92$ https://www.researchgate.net/profile/Farhan_Ahmed15/publication/333 103811_Servant_Leadership_Improves_the_Knowledge_Sharing_Beh avior_of_Employees_in_Organization_A_Case_of_Higher_Education_ Sector_in_Pakistan/links/5cdbb6f0458515712eac24c5/Servant-Leaders hip-Improves-the-Knowledge-Sharing-Behavior-of-Employees-in-Orga nization-A-Case-of-Higher-Education-Sector-in-Pakistan.pdf

25. H. Latan, Structural equation modeling: Konsep dan aplikasi menggunakan program LISREL 8.80. Bandung: Alfabeta, 2012.

26. Jr. C. Lindquist, and E. Russell. (2019). Fire and emergency services perceptions of servant leadership and job satisfaction. Servant Leadership: Theory \& Practice, Vol. 6, No. 1, pp. 3. https://csuepress.columbusstate.edu/sltp/vol6/iss1/3/

27. N. Rüzgar, B. Özkan, and A.N. Odabaşoğlu. (2019). The relationship between mayors' servant leadership styles and quality of city life. IBAD Sosyal Bilimler Dergisi, Vol. 5, pp. 598-614. https://dergipark.org.tr/en/pub/ibad/issue/47758/648394

28. M. Heidari, S. Ghasemi, and R. Heidari. (2019). The effects of leadership and employment in technical capabilities of sport teams. Journal of Humanities Insights, Vol. 3, No. 02, pp. 75-80. http://www.jhumanities.net/article_80900_10337.html

29. O.M. Karatepe, A. Ozturk, and T.T. Kim. (2019). Servant leadership, organisational trust, and bank employee outcomes. The Service Industries Journal, Vol. 39, No. 2, pp. 86-108. https://www.tandfonline.com/doi/abs/10.1080/02642069.2018.1464559

30. D.H. Jung, and J.H. Seo. (2019). The effects of female CEO leadership on organizational commitment and organizational citizenship behavior: With a focus on transformational leadership and servant leadership. Journal of the Korea Academia-Industrial cooperation Society, Vol. 20, No. 3, pp. 377-385.

31. http://www.koreascience.or.kr/article/JAKO201913458198029.page

32. A.K. Adelekan. (2019). Identification and measurement of servant leadership in early childhood: Parent perspectives. Doctoral dissertation, Regent University. http://search.proquest.com/openview/63ec7e68d49a56ee314a59162db0 540d/1 ?pq-origsite $=$ gscholar\&cbl $=18750 \&$ diss $=y$

33. P.R. Mullen, D. Limberg, V. Tuazon, and S.M. Romagnolo. (2019). Emotional intelligence and leadership attributes of school counselor trainees. Counselor Education and Supervision, Vol. 58, No. 2, pp 112-126. https://onlinelibrary.wiley.com/doi/abs/10.1002/ceas.12135

34. J.A. Irving. (2005). Servant leadership and the effectiveness of teams. Regent University Dissertation. http://www.academia.edu/download/44854521/Irving_Justin-RegentUn iversity_final.pdf

35. H. Latan, Structural equation modeling concepts and applications using LISREL 8.80 (In Indonesia). Bandung: Alfabeta, 2012.

Published By: 
36. H.M. Jogiyanto, Concept and application of structural equation modeling based on variants in business research (In Indonesia).Yogyakarta.: UPP STIM YKPN, 2011.

37. J.F. Hair, W.C. Black, B.J. Babin and R.E. Anderson, Multivariate data analysis. Upper Saddle River: Prentice Hall, 2010.

38. W. Abdillah, and J. Hartono, Partial least square (PLS): Alternatif structural equation modeling (SEM) dalam penelitian bisnis. Yogyakarta: Andi, 2015.

39. S. Atkinson, and D. Butcher. (2003). Trust in the context of management relationships: an empirical study. https://dspace.lib.cranfield.ac.uk/handle/1826/3253

40. N.K. Jaiswal, and R.L. Dhar. (2017). The influence of servant leadership, trust in leader and thriving on employee creativity. Leadership \& Organization Development Journal. https:/www.emerald.com/insight/content/doi/10.1108/LODJ-02-20150017/full/html

41. J.D. Politis, and D.J. Politis. (2017). The role of servant leadership on interpersonal trust and performance: The mediating influence of interpersonal trust. In 13th European Conference on Management, Leadership and Governance: ECMLG (p. 382). https://www.google.com/books?hl=id\&lr=\&id=5blDDwAAQBAJ\&oi= fnd\&pg=PA382\&dq=The+role+of+servant+leadership+on+interperson al+trust+and+performance:+The+mediating+influence+of+interperson al+trust.\&ots=Zn0SOg1_L4\&sig=S00n-ubede2RNjWv2o-vyX_Rc_I

42. M. Sousa, and D. van Dierendonck. (2017). Servant leadership and the effect of the interaction between humility, action, and hierarchical power on follower engagement. Journal of Business Ethics, Vol.141, No. 1, pp. 13-25. https://link.springer.com/article/10.1007/s10551-015-2725-y

43. E.J. Krumrei-Mancuso. (2018). Humility in servant leadership among Christian student leaders: A longitudinal pilot study. Journal of Psychology and Theology, Vol. 46, No. 4, pp. 253-267. https://journals.sagepub.com/doi/abs/10.1177/0091647118807177

44. Rasheed, A., Lodhi, R. N., and Habiba, U. (2016). An empirical study of the impact of servant leadership on employee innovative work behavior with the mediating effect of work engagement: Evidence from banking sector of Pakistan. Global Management Journal for Academic \& Corporate Studies, Vol. 6, No. 2 . http://search.proquest.com/openview/9da8a931cb3a8348a0ec15c0e80b 4d7d/1 ?pq-origsite $=$ gscholar\&cbl $=2027551$

45. N. Al Amiri, F. Daradkeh, and A. Al Kaabi. (2019). Leadership styles and competence among generation $\mathrm{Z}$ emirati nursing students. International Journal of Learning, Teaching and Educational Research, Vol. 18 , No.

https://www.researchgate.net/profile/Nabeel_Al_Amiri2/publication/33 6238901_Leadership_Styles_and_Competence_among_Generation_Z_ Emirati_Nursing_Students/links/5d96623e92851c2f70e81b4a/Leadersh ip-Styles-and-Competence-among-Generation-Z-Emirati-Nursing-Stud ents.pdf

\section{AUTHORS PROFILE}

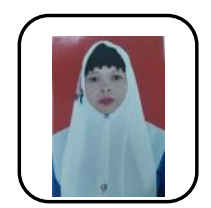

Arifah was born on April 24, 1976 in Yogyakarta. She is a student at Master of Psychology, Universitas Ahmad Dahlan, Yogyakarta. Her scientific focus is educational psychology.

Fatwa Tentama was born on October 1, 1984 in

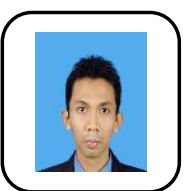
Yogyakarta. Working as a lecturer at the Faculty of Psychology at Ahmad Dahlan University, Yogyakarta. His scientific focus and research is industrial psychology and educational psychology.

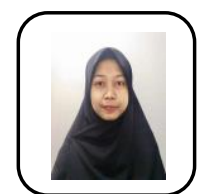

Pipih Muhopilah was born on January 7, 1996 in Majalengka. She is a student at Master of Psychology, Universitas Ahmad Dahlan, Yogyakarta. At present her concentration of scientific fields is positive psychology and educational psychology.

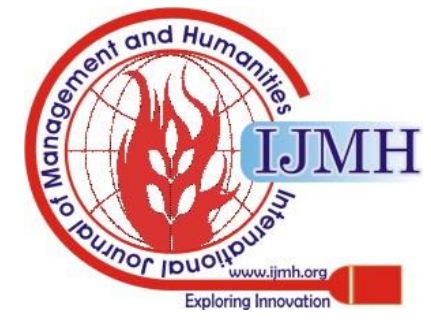

